\title{
Effect Of Some Herbal Medicine On Some biochemical paramcters In Diabetic Rats
}

\author{
Eman G.E. Helal, Mervat A.Abbas* \\ Department of Zoology, Faculty of science (Girls) and Department of Biochemistry* \\ Faculty of Medicine for Girls Al Azhar University.
}

\begin{abstract}
The current study was planned to follow up the effect of famous mixture used as a hypoglycemic traditional medicine in Saudi Arabia on diabetic albino rats and their effects on some biochemical parameter as DHEA . This study also aimed to study the effect of each plants alone to illustrate the most powerful one of them.

The present study was carried out on eighty adult male albino rats $(120 \pm 20 \mathrm{gm} \mathrm{b} . w t)$. They were randomly divided into eight groups. First group conserved as control group.The others groups received alloxan to become diabetic .The second group conserved as diabetic, the third group treated with a mixture of plants $(0.5 \mathrm{gm} / 120 \mathrm{gm} \mathrm{b}$. $\mathrm{wt})$.From he fourth to eight group,the rats treated with Nigella sativa $(0.25 \mathrm{gm} / 120 \mathrm{gm} \quad \mathrm{b} . \mathrm{wt})$,Aloe vera,Ferulaassa-foetid,Boswellia Carterii Birdw and Commiphora myrrha respectively $(0.5 \mathrm{gm} / 120 \mathrm{gm}$ b.wt.).Our result showed that the body weight was reduced significantly in diabetic group and Nigella sativa treated group. On the other hand, treatment with commiphora myrrha revealed significant increase in body weight gain, while mixture and Aloe vera treated rats recorded insignificant change. Diabetic rats revealed a significant decrease in serum glucose and DHEA-S levels and liver glycogen content, while insignificant difference was recoded in all treated groups. A significant decrease in serum insulin level was observed in diabetic group, Nigella sativa and Ferula assafoetida treated groups, but insignificant different was recorded in the rest treated groups throughout the experiment. A significant increase in LDH activities in diabetic and Ferula assafoetida treated groups was recorded while rest treated groups recorded insignificant change During experimental period.
\end{abstract}

\section{Introduction}

Diabetes mellitus is a condition in which there is a chronically raised blood glucose concentration. it is caused by an absolute or relative lack of insulin, where insulin is not being produced from the pancreas or there is insufficient insulin or insulin action for the body's needs (Gareth-Williams et al., 2000) .Diabetes affects $20 \%$ of the population over the age of $65 \%$ years, and more than $90 \%$ of the older people with diabetes are type II diabetics (Dawson, 1998). Most patients of this form of diabetes are obese and their glucose tolerance improves if they lose weight, (Ganang, 2003).

The effects of insulin on glucose metabolism are that insulin stimalates glycerol syuthesis and inhibits lipase activity in adipose cells. Circulating insulin also increases the amount of amino acids taken up by the cell and inhibits protein catabolism. Insulin appears to be essential for normal cell growth and function (Micheal et al. 2003).

Dehydroepiandrosterone (DHEA) And its metabolite DHEA sulfate are the most abundant circulating adrenal storids in humans. DHEA has been shown to modulate glucose utilization in humans and animals, but the mechanisms of DHEA action have not been clarified. The decline in circulating DHEA levels occuring with aging has been linked to the gradually increasing prevelance of atherosclerosis, obesity and diabetes in elderly individual (perrini et al., 2004). 


\section{Eman G.E. Helal \& Mervat A.Abbas}

Dehydroepiandrosterone (DHEA) and its sulphate derivative (DHEA-s) have antidiabetic and antiobesity effects. Administration of $0.4 \%$ DHEA in the diet reversed hyperglycemia, preserved beta-cell function, and increase insulin sensitivity in genetically diabetic mice. DHEA increases m-RNA through binding to a specific factor in cultured human fibroblasts and there by stimulating glucose up take in these cells (Nakashima et al., 1995). DHEA was shown to protect against the development of visceral obesity and muscle insulin resistance in rats feed a high-fat diet (Hansen et al.,1997) Recent study has report that DHEA increases glucose up take rates in human fibroblast and rat adiposities ( perrini et al.,2004)

There are many plants and plants extracts which possess marked hypoglycemic activity. They appear to be the active hypoglycemic principles suggests different sites of action within the body polysaccharides feature (puri et al. 1994).

Nigella sativa (Black cumin) has long been used as a natural medicine for treatment of many acute as well as chronic conditions. It has been used in treatment of diabetes, hypertension and dermatological conditions ( Meral et al., 2001)

Aloe vera has been used all over the world of their various medicinal properties. There have been controversial reports on the hypolgycemic activity of Aloe species, probably due to differences in the parts of the plant used or to the model of diabetic chosen (Okyar et al., 2001).

Ferula assa-Foetida is the best remedy for clearing gas and bloating. The volatile oil of it contian, disulphides, which have an expectorant action settles digestion. It also lowers blood pressure (Chevalier, 1996). Sulfur compound in the oil may protect against fat-induced hyperlipdemia (Duke, 2002).

Boswellia carterri has been used historically in medical system of India including arthritis and other inflammatory conditions .Hayashi (1998) confirmed that B.carterri contains actyl acetate and actanol as main constituents.

Commiphora myrrha (Myrrh) is one of the oldest known medicine. It useful for skin problems, atherosclerosis, hemorrhoid, heptoses, high cholesterol, stomatosis, immunodepression and hyperglycemia (Duke, 2002).

There are many possible site of actions at which such previous plants could act to lower glucose level (Olefsky, 1981), for example agents which inhibit lipolysis and promote glucose uptake by active metabolizing tissues (Hales, 1986). Agents which sequester counterregulatory hormones such as growth hormone or binding protiens agents which increase thermogenesis by enhancing glucose utilization through futile cycling (Coleman et al., 1982). Agents which increase physical activity (Vignati and Cunningham; 1985). Therefore ,the present study aimed to examine the influence of oral administration of this mixture and of each one of this herbs on the level of some biochemical parameters in serum and liver of alloxaninduced diabetic rats.

\section{Material and Methods}

The present work was carried out on eighty male albino rats, weight $120+20 \mathrm{gm}$. They are obtained from NAMRU medical center. The experimental animals were randomly divided into eight groups (10/cage) and fed on rodent diet and some vegtables, the rats stayed for 2 weeks to adapte the place then began the experimental steps. Five antidiabetic plants extracts were used. These plants are: Nigella sative, commiphora myrrha, Boswellia carterii Birdw, Ferula assa-foetida and Aloe vera which were brought from market. These plants were used as a mixture then each one was water extracted alone.

Rats were assigned randomly to eight groups. Seven of them are fasted over night, then rats were injected with a single subcutaneous dose of freshly prepared alloxan in adose $120 \mathrm{mg} / \mathrm{kg}$ b.wt. Dissolved in $0.5 \mathrm{ml}$ acetate buffer ( $p h 5.5$ ) according to (Malaisse, 1982). Alloxan is a uric acid derivative used as acommon chemical for inducing diabetes. The first group served as control. After 48 hours of alloxan injection, blood glucose level was measured. Rats with fasting blood glucose level more thadn 
$250 \mathrm{mg} / \mathrm{dl}$ considered diabetic. Seven days later, rats were treated with herbal medicine as the following:-

Group I : served as control.

Group II : rats treated with alloxan served as diabetic.

Group III: Diabetic rats treated with the mixture of the tested plants. The dose used were $1 \mathrm{ml} / 100 \mathrm{gm}$ b.wt. where the plants were grinned and $10 \mathrm{gm}$ of each plant were mixed and boiled in $100 \mathrm{ml}$ dist.water for a period $10 \mathrm{~min}$,so the plants concentration were $0.5 \mathrm{gm} / 120 \mathrm{gm}$ b.wt.

Group IV: Diabetic rats treated with Nigella Sativa. $(0.25 \mathrm{gm} / 120 \mathrm{gm}$ b.wt.) in a dose $1 \mathrm{ml} / 100 \mathrm{gm}$ b.wt.)

Group V: Diabetic rats treated with Aloe Vera. $\quad 0.5 \mathrm{gm} / 120 \mathrm{gm}$ b.wt.in a dose $0.5 \mathrm{ml} / 100 \mathrm{gm}$ b.wt(we used the half dose because some rats died .

Group VI: Diabetic rats treated with Ferula assa- foetida $0.5 \mathrm{gm} / 120 \mathrm{gm}$ b.wt. In a dose $1 \mathrm{ml} / 100 \mathrm{gm}$ b.wt.

Group VII: Diabetic rats treated with Boswellia carterii Birdw $0.5 \mathrm{gm} / 120 \mathrm{gm}$ b.wt. In a dose 1ml/100gm b.wt.

Group VIII: Diabetic rats treated with commiphora myrrha $0.5 \mathrm{gm} / 120 \mathrm{gm}$ b.wt. In a dose $0.5 \mathrm{ml} / 100 \mathrm{gm}$ b.wt(we used the half dose because some rats died)

After 30 days of treatment, animals of each group were decapitated. After animal dissection, the liver was obtained and stored at $(-80 \mathrm{c})$ for determination of glycogen. Blood samples were collected in dry centrifuge tubes, centrifuged at $500 \mathrm{rpm}$ for $10 \mathrm{~min}$ and serums were separated.

\section{Biochemical analysis:-}

-Assessment of serum glucose level: According to the enzymatic colorimetric method described by Tietz (1986).

-Determination of liver glycogen content: The technique adopted was described by Joseph (1955).

-Determination of serum insulin level: This method is carried out according to Reeves (1983).
-Determination of serum DHEA-s (Dehydroepiandrosterone) level by DHEA Elisa kit.(yen et al.,1977).

-Determination of serum LDH concentration according to the method of kachmar and moss (1976).

-Assessment of serum alkaline phosphatase concentration according to the method of John (1982).

\section{Statistical analysis :-}

Data of the studies were presented as means \pm standard error $\mathrm{SE}$ and $\mathrm{T}$ test according to snedecor and cochran (1980).

Results were considered significant when $\mathrm{p}$ $<(0.05)$ and highly significant .when $\mathrm{p}<$ $(0.01)$

\section{Results}

The results of this study showed that the body weight was reduced significantly in diabetic group and Nigella sativa treated group. On the other hand, treatment with commiphora myrrha revealed significant increase in body weight gain, while mixture and Aloe vera treated rats recorded insignificant change (Table and Figure1). Diabetic rats revealed a significant decrease in serum glucose and DHEA-S levels and liver glycogen content, while insignificant difference was recoded in all treated groups (Table and figure2,3,5) and a significant decrease in serum insulin level was observed in diabetic group,Nigella sativa and Ferula assa-foetida treated groups, but insignificant different was recorded in the rest treated groups throughout the experiment in a comparion with the control group(Table and figure 4). A significant increase in LDH activities in diabetic and Ferula assa-foetida treated groups was recorded while rest treated groups recorded insignificant change during experimental period as compared with normal rats. (Table and figure5, 6). 
Table (1): Percentage of body weight change in control, diabetic and plant extracts treated

\begin{tabular}{|c|c|c|c|c|c|c|c|c|c|}
\hline \multirow[b]{2}{*}{ 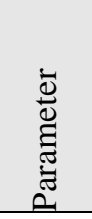 } & \multirow[b]{2}{*}{$\begin{array}{l}\tilde{Z}_{\bar{Z}} \\
\hat{0}_{0}\end{array}$} & \multicolumn{8}{|c|}{ Treatment period (4 weeks) } \\
\hline & & Control & Diabetic & Mixture & $\begin{array}{l}\text { Nigella } \\
\text { Sativa }\end{array}$ & $\begin{array}{l}\text { Aloe } \\
\text { vera }\end{array}$ & $\begin{array}{l}\text { Ferula } \\
\text { assa- } \\
\text { foetida }\end{array}$ & $\begin{array}{l}\text { Boswellia } \\
\text { Carterii } \\
\text { Birdw }\end{array}$ & $\begin{array}{l}\text { Commi } \\
\text { Phora } \\
\text { myrrha }\end{array}$ \\
\hline \multirow{4}{*}{ 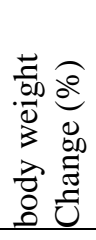 } & Mean & 35.99 & 9.42 & 33.78 & 23.52 & 37.39 & 55.72 & 40.72 & 40.04 \\
\hline & $\pm \mathrm{SE}$ & 1.02 & 0.96 & 1.87 & 0.82 & 0.37 & 0.77 & 0.95 & 0.49 \\
\hline & A & & $* *$ & & $* *$ & & $* *$ & $*$ & $* *$ \\
\hline & B & & & $* *$ & $* *$ & $* *$ & $* *$ & $* *$ & $* *$ \\
\hline
\end{tabular}

rats after 4 weeks of treatment.

A - in comparison with control group.

B- in comparison with diabetic group.

$* \mathrm{p}<0.05$.

** $\mathrm{p}<0.01$.

Fig (1): Percentage of body weight change in control, diabetic and plant extracts treated

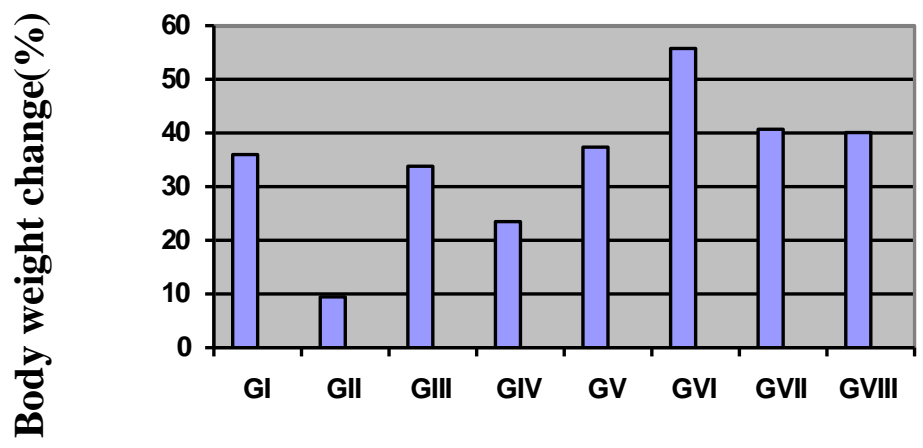

Table (2): Serum glucose level $(\mathrm{mg} / \mathrm{dl})$ in control, diabetic and plant extract treated rats after 4 weeks of treatment.

\begin{tabular}{|c|c|c|c|c|c|c|c|c|c|}
\hline \multirow[b]{2}{*}{ 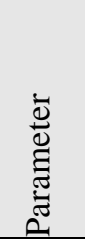 } & \multirow[b]{2}{*}{$\begin{array}{l}\tilde{\Xi} \\
\stackrel{0}{0}\end{array}$} & \multicolumn{8}{|c|}{ Treated period (4 weeks ) } \\
\hline & & control & diabetic & mixture & $\begin{array}{l}\text { Nigella } \\
\text { sativa }\end{array}$ & $\begin{array}{l}\text { Aloe } \\
\text { vera }\end{array}$ & $\begin{array}{l}\text { Ferula } \\
\text { assafoctida }\end{array}$ & $\begin{array}{l}\text { Boswellia } \\
\text { carterii } \\
\text { birdw }\end{array}$ & $\begin{array}{l}\text { Commiphora } \\
\text { myrrha }\end{array}$ \\
\hline \multirow{4}{*}{ 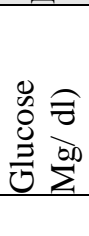 } & mean & 136.8 & 266.8 & 134.8 & 131.2 & 139.2 & 135.0 & 137.8 & 135.6 \\
\hline & \pm se & 0.86 & 0.41 & 0.37 & 1.99 & 0.75 & 0.32 & 0.58 & 0.51 \\
\hline & $\mathrm{A}$ & & $* *$ & & & & & & \\
\hline & $\mathrm{B}$ & & & $* *$ & ** & $* *$ & $* *$ & ** & ** \\
\hline
\end{tabular}


Fig ( 2 ) : serum glucose level in control, diabetic and plant treated male albino rats after 4 weeks of treatment.

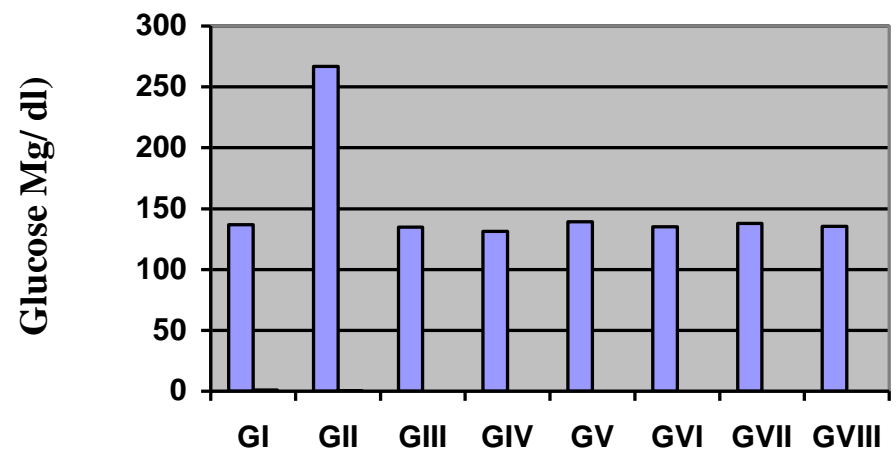

Table (3): Glycogen content in the liver ( $\mathrm{mg} / \mathrm{dl})$ in normal diabetic and plant extract treated rats after 4 weeks of treatment

\begin{tabular}{|c|c|c|c|c|c|c|c|c|c|}
\hline \multirow[b]{2}{*}{ 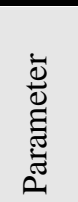 } & \multirow[b]{2}{*}{ 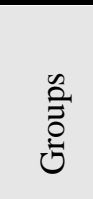 } & \multicolumn{8}{|c|}{ Treated period (4 weeks ) } \\
\hline & & control & diabetic & mixture & $\begin{array}{c}\text { Nigella } \\
\text { sativa }\end{array}$ & $\begin{array}{l}\text { Aloe } \\
\text { vera }\end{array}$ & $\begin{array}{c}\text { Ferula } \\
\text { assafoctida }\end{array}$ & $\begin{array}{c}\text { Boswellia } \\
\text { carterii } \\
\text { birdw }\end{array}$ & $\begin{array}{c}\text { Commiphora } \\
\text { myrrha }\end{array}$ \\
\hline \multirow{3}{*}{ 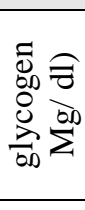 } & mean & 173.2 & 162.69 & 175.15 & 169.93 & 176.11 & 172.72 & 170.16 & 173.92 \\
\hline & $\pm \mathrm{se}$ & 0.875 & 0.715 & 0.782 & 0.848 & 0.480 & 0.570 & 0.590 & 0.590 \\
\hline & $\bar{A}$ & & $* *$ & & & & & & \\
\hline & B & & & $* *$ & ** & $* *$ & $* *$ & $* *$ & $* *$ \\
\hline & & & & & & & & & \\
\hline
\end{tabular}

Fig ( 3 ) : Glycogen content in the liver in control, diabetic and plant treated male albino rats after 4 weeks of treatment.

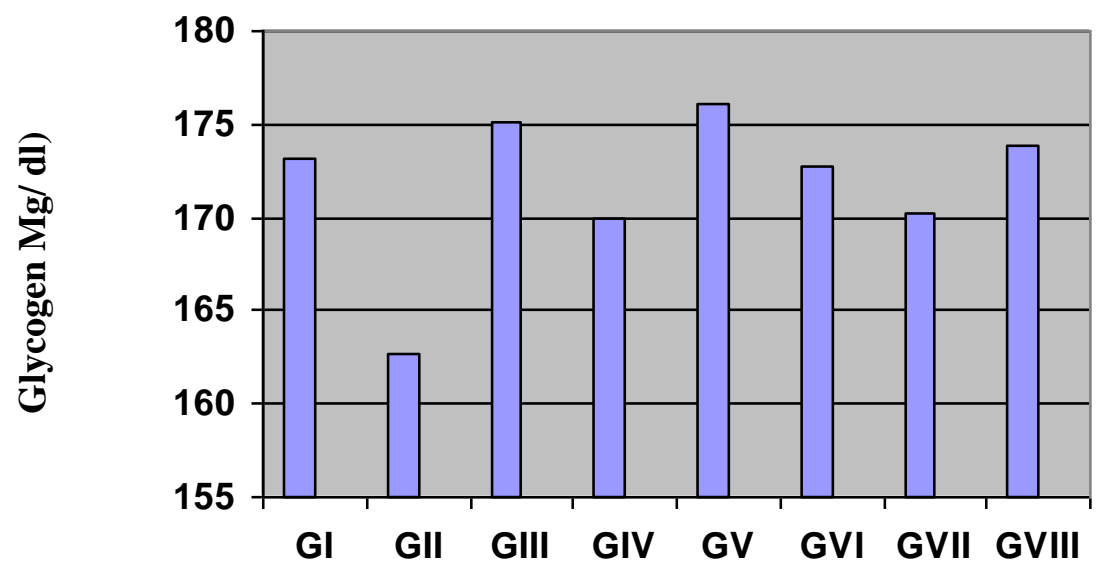


Table (4): Serum insulin level in normal, diabetic and plant extracts treated albino rats after 4 weeks of treatment .

\begin{tabular}{|c|c|c|c|c|c|c|c|c|c|}
\hline \multirow[b]{2}{*}{ 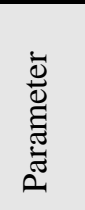 } & \multirow[b]{2}{*}{ 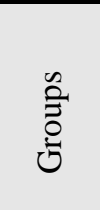 } & \multicolumn{8}{|c|}{ Treated period (4 weeks ) } \\
\hline & & control & diabetic & mixture & $\begin{array}{c}\text { Nigella } \\
\text { sativa }\end{array}$ & $\begin{array}{l}\text { Aloe } \\
\text { vera }\end{array}$ & $\begin{array}{c}\text { Ferula } \\
\text { assafoctida }\end{array}$ & $\begin{array}{l}\text { Boswellia } \\
\text { carterii } \\
\text { birdw }\end{array}$ & $\begin{array}{c}\text { Commiphora } \\
\text { myrrha }\end{array}$ \\
\hline \multirow{4}{*}{ 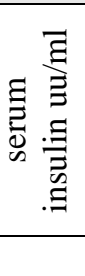 } & mean & 41.60 & 20.60 & 41.00 & 32.40 & 39.20 & 25.60 & 37.60 & 39.70 \\
\hline & $\pm \mathrm{se}$ & 1.51 & 1.81 & 1.22 & 1.44 & 1.32 & 1.57 & 1.51 & 1.60 \\
\hline & $\bar{A}$ & & $* *$ & & $* *$ & & $* *$ & & \\
\hline & $B$ & & & ** & $* *$ & $* *$ & $* *$ & $* *$ & $* *$ \\
\hline
\end{tabular}

Fig (4): Serum insulin level in control, diabetic and plant treated male albino rats after 4 weeks of treatment.

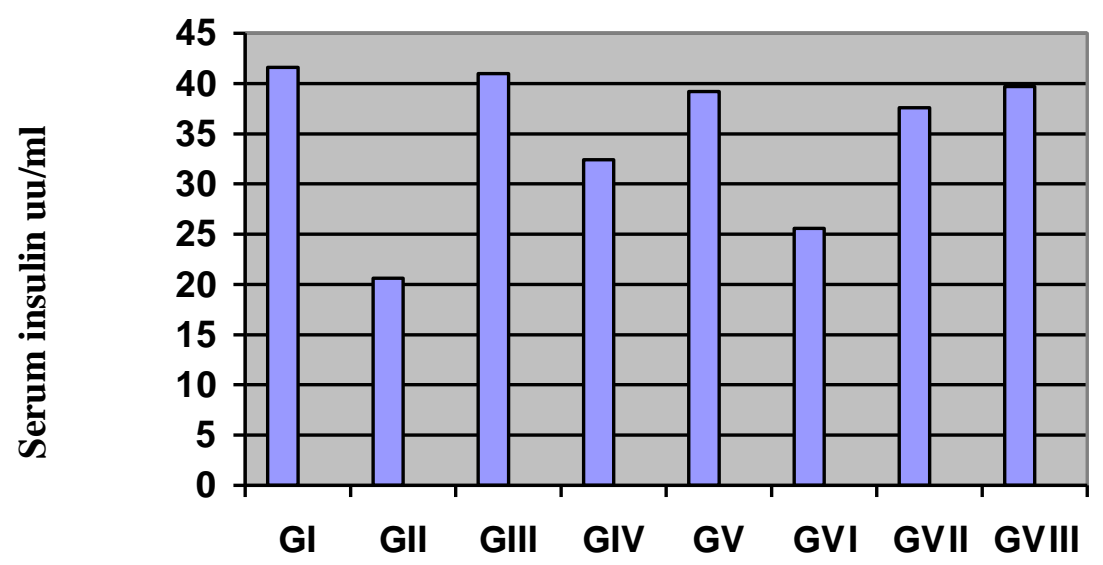

Table (5): Serum DHEA- S level in control, diabtic and plant extracts treated albino rats after 4 weeks of treatment.

\begin{tabular}{|c|c|c|c|c|c|c|c|c|c|}
\hline \multirow[b]{2}{*}{$\begin{array}{l}\dot{\bar{U}} \\
\stackrel{\Xi}{\Xi} \\
\bar{\Xi} \\
0\end{array}$} & \multirow[b]{2}{*}{ 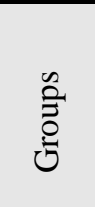 } & \multicolumn{8}{|c|}{ Treated period (4 weeks ) } \\
\hline & & control & diabetic & mixture & $\begin{array}{c}\text { Nigella } \\
\text { sativa }\end{array}$ & $\begin{array}{l}\text { Aloe } \\
\text { vera }\end{array}$ & $\begin{array}{c}\text { Ferula } \\
\text { assafoctida }\end{array}$ & $\begin{array}{c}\text { Boswellia } \\
\text { carterii } \\
\text { birdw }\end{array}$ & $\begin{array}{c}\text { Commiphora } \\
\text { myrrha }\end{array}$ \\
\hline \multirow{4}{*}{ 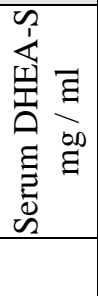 } & mean & 0.32 & 0.26 & 0.34 & 0.31 & 0.34 & 0.33 & 0.33 & 0.35 \\
\hline & $\pm \mathrm{se}$ & 0.05 & 0.08 & 0.08 & 0.29 & 0.15 & 0.17 & 0.06 & 0.09 \\
\hline & A & & $* *$ & & & & & & \\
\hline & B & & & $* *$ & $* *$ & $* *$ & $* *$ & $* *$ & $* *$ \\
\hline
\end{tabular}


Fig ( 5 ) : Serum DHEA-S level in control, diabetic and plant treated male albino rats after 4 weeks of treatment.

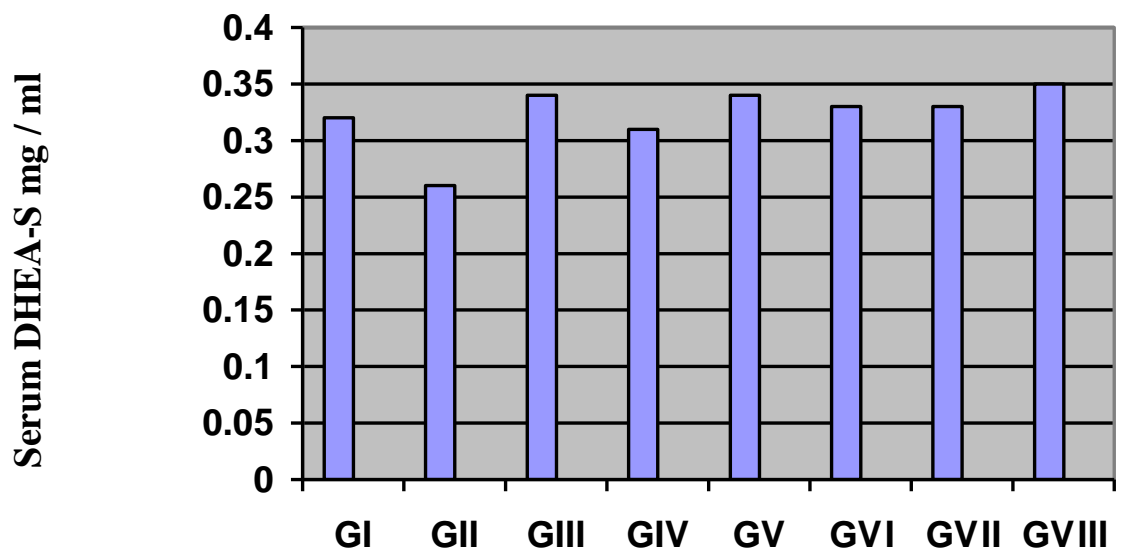

Table (6): Lactate dehydrogenase (LDH) activity in control, diabetic and plant extracts treated rats after 4 weeks of treatment.

\begin{tabular}{|c|c|c|c|c|c|c|c|c|c|}
\hline \multirow[b]{2}{*}{$\begin{array}{l}\overline{\bar{d}} \\
\bar{\Xi} \\
\bar{\Xi} \\
\bar{\Xi}\end{array}$} & \multirow[b]{2}{*}{ 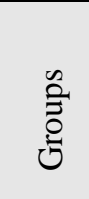 } & \multicolumn{8}{|c|}{ Treated period (4 weeks) } \\
\hline & & control & diabetic & mixture & $\begin{array}{c}\text { Nigella } \\
\text { sativa }\end{array}$ & $\begin{array}{l}\text { Aloe } \\
\text { vera }\end{array}$ & $\begin{array}{c}\text { Ferula } \\
\text { assafoctida }\end{array}$ & $\begin{array}{c}\text { Boswellia } \\
\text { carterii } \\
\text { birdw }\end{array}$ & $\begin{array}{c}\text { Commiphora } \\
\text { myrrha }\end{array}$ \\
\hline \multirow{4}{*}{ 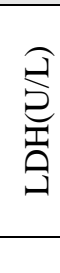 } & mean & 95.42 & 192.42 & 94.60 & 94.16 & 96.00 & 98.46 & 95.04 & 94.62 \\
\hline & $\pm \mathrm{se}$ & 0.76 & 0.81 & 0.72 & 0.77 & 0.85 & 0.94 & 0.73 & 0.71 \\
\hline & A & & ** & & & & * & & \\
\hline & B & & & ** & *** & *** & ** & ** & *** \\
\hline
\end{tabular}

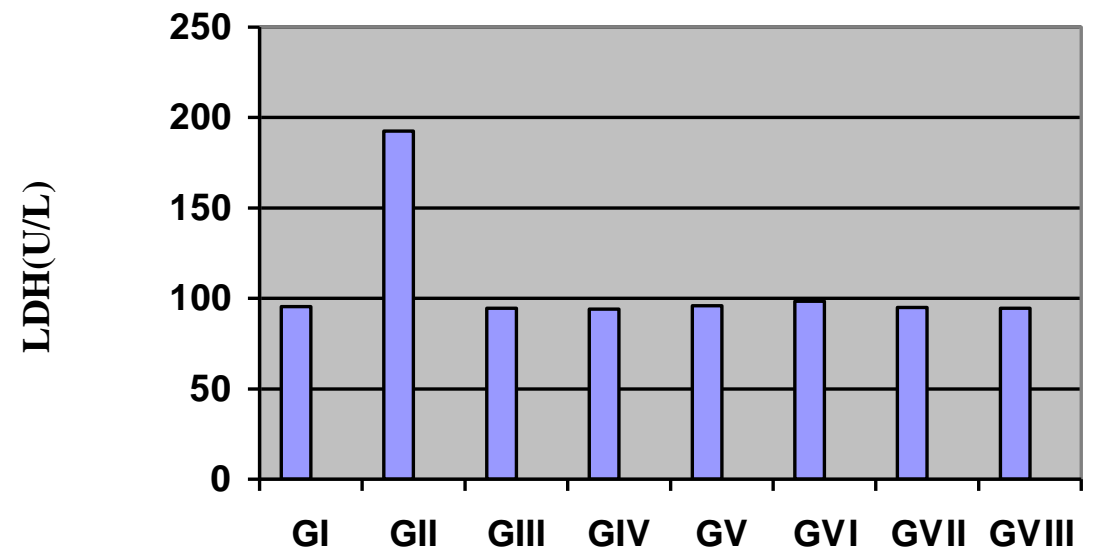

Fig ( 6 ) : Serum lactate dehydrogenase (LDH) activity in control, diabetic and plant treated male albino rats after 4 weeks of treatment. 
Table (7): Alkaline phosphatase activity in control, diabetic and plant extracts treated rats after 4 weeks of treatment.

\begin{tabular}{|c|c|c|c|c|c|c|c|c|c|}
\hline \multirow[b]{2}{*}{ 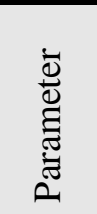 } & \multirow[b]{2}{*}{$\begin{array}{l}\stackrel{0}{二} \\
\stackrel{0}{0} \\
\stackrel{0}{0}\end{array}$} & \multicolumn{8}{|c|}{ Treated period (4 weeks) } \\
\hline & & control & diabetic & mixture & $\begin{array}{l}\text { Nigella } \\
\text { sativa }\end{array}$ & $\begin{array}{l}\text { Aloe } \\
\text { vera }\end{array}$ & $\begin{array}{c}\text { Ferula } \\
\text { assafoctida }\end{array}$ & $\begin{array}{c}\text { Boswellia } \\
\text { carterii } \\
\text { birdw }\end{array}$ & $\begin{array}{c}\text { Commiphora } \\
\text { myrrha }\end{array}$ \\
\hline \multirow{4}{*}{ 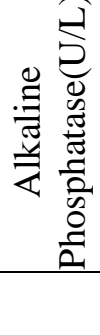 } & mean & 91.38 & 116.84 & 91.64 & 92.98 & 92.30 & 94.30 & 90.32 & 90.92 \\
\hline & \pm se & 0.33 & 0.45 & 0.40 & 0.96 & 0.51 & 1.08 & 0.83 & 0.74 \\
\hline & A & & $* *$ & & & & $*$ & & \\
\hline & B & & & $* *$ & $* *$ & $* *$ & $* *$ & $* *$ & $* *$ \\
\hline
\end{tabular}

Fig ( 7 ) : Serum alkaline phosphatase activity in control, diabetic and plant treated male albino rats after 4 weeks of treatment.

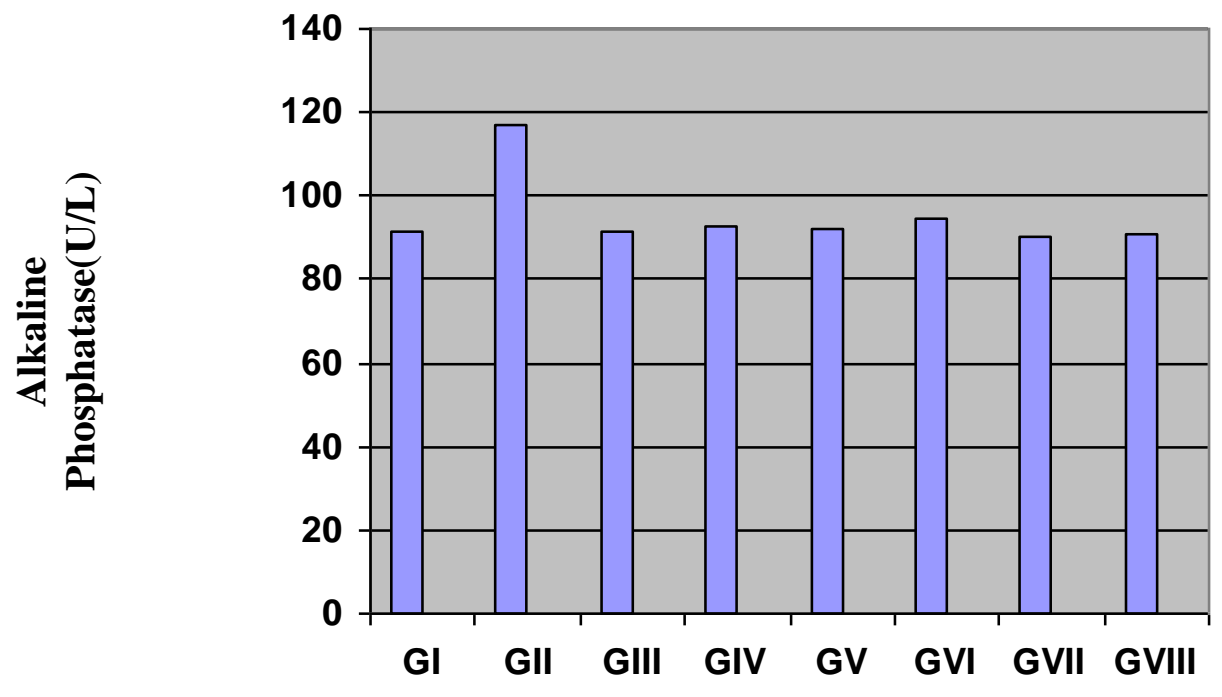

\section{Discussion}

Traditional antidiabetic plants might provide useful source of new oral hypoglycemic compounds for development as pharmaceutical entities, or as simple dietary adjuncts to existing therapies.

A scientific investigation of traditional herbal remedies for diabetes mellitus may provide valuable leads for the development of alternative drugs and therapeutic strategies. Alternative are clearly needed because of the inability of current therapies to control high cost and poor availability of current therapies for many rural population, particularly in developing countries. ( Morles and Farnsworth, 1995 ).

Our data, showed an increase in the body weight gain in all treated groups when compared with diabetic one. Data recorded is in agreement with the findings of alawadi et al. (1991). Where, they reported that the treatment with the antidiabetic plants mixture (Nigella sativa, Commiphora myrrha Geum urbanium, Ferula assafoetida and Aloie vera) used by Kuwaiti 
diabetic individuals prevented reduction in body weight observed in diabetic animals.

This mixture may stimulate most aspects of carbohydrate metabolism, includeeing rapid uptake of glucose by the cells, enhanced glycloysis, enhanced gluconeogenesis,increased rate of absorption from the gastrointestinal tract and even increased insulin secretion with its resultant secondary effects on carbohydrate metabolism (Guyton and Hall,2000)

While, Nigella sativa treated group showed a decrease in the body weight gain when compared with control group. This probably rise from its claim to result in nutrient partitoning so that ingested calories will be directed to muscle, rather than fat and /or attempt to physically affect gastric satiety by filling the stomach (Heber,2003). And possibly spring from its anti water retention action (Duke, 2002). Or may be attributed to increase plasma leptin concentration which travels to the appetite control center in the brain and tells it to stop eating ( Ebihara et al., 2001)

In the present investigation, the treatment of diabtic rats with mixture and Boswellia carterii Birdw caused a significant hypoglycemic effect with a significant increase in serum insulin level. In agreement with these findings Al-Awadi et al. (1988) reported that the mixture of previous plants is a potent hypoglycemic agent. The antidiabetic action of these plants extract may, at least partly, be mediated through decreased hepatic gluconeogenesis (Al- Awadi et al., 1991).The decreasing of blood glucose level by the mixture and Boswellia carteii Birdw is secondary to enhanced insulin secretion, decreased insulin resistance and glycogen synthesiss activation. It seems to have a direct action on insulin secretion through stimulation of secretion of the golgi complex (Bever and zahand, 1979) or it may stimulate insulin secretion through the B-cell receptor and possibly through a direct effect on intracellular calcium transport (Campbell et al., 1991).

While the hypoglycemic and hyperinsulinemic activities of Cmmiphora myrrha may be attributed to it's phytosterols, which have a hormonal action (Chevallier, 1996) or, to its plysaccharides content which have hypoglycemic activity in animals (Evans, 2001). In contrast to the present data Duke et al., (2002) reported that Commiphora myrrha had antihypoglycemic activities.

In the present study, the decrease in liver glycogen content of diabetic rats may be a result of increasing glucose output during insulin deficiency (Gold, 1970). And may be due to the loss of glycogen synthetase-activating system (Annamala and Augusti, 1980) and/or increased activity of glucose-6- phosphatase (Abdelmoniem et al., 2001). It is possible that the increase in liver glycogen content after treatment with the extract of mixture is a result of increased insulin level which has a potent effect on glycogen synthetase activity as well as on hepatic hexokinase and glycogen-6-phosphatase activity (Sheela and Augusti , 1992).

The present data, showed highly significant decrease in serum dehydroepiandrsterone-sulfate (DHEA-S) level in diabetic group as compared with control one. This decrease in serum DHEA-S concentration may be due to the effect of alloxan on adrenal gland. Decreasing of DHEA-S concentration leads to decrease in serum insulin level which associted with serum insulin concentration (Aoki et al., 2003).After the treatment of rats with mixture water extract, the serum concentration of DHEA-S was increased. This may be due to the ameliorating effect of plant extraction on the hazardous effect of alloxan and this leads to increasing serum insulin concentration. Where, DHEA decreased hyperglycemia in diabetic mice, which become insulin resistant by increasing not only insulin sensitivity due to its effects on the liver and muscle, but also on insulin secretion from B-cells (Aoki et al., 2003).

Numerous studies show that insulin activity, DHEA levels, and glucose homeostasis are all important synergistic factors in the onset and progression of diabetes (Casson et al 1995).

Animal studaes have shown thet DHEA guerds against and / or reduces insulin resistanca providing a benefit similar to that of exercise ( hansen. et al, 


\section{Eman G.E. Helal \& Mervat A.Abbas}

1997 ) . In general, insulin resistance and hyperinsulin- emia are associatad with low circulating levels of DHEA, especially in men ( Loviselli et al, 1994 ).

In the present work, there was a highly significant increase in the activity of LDH and alkaline phosphatase in alloxan diabetic rats. This finding was in agreement with that of Yadav et al. (1997), who stated that increased level of blood glucose in diabetes produce superoxide anions and hydroxyl radicals in the presence of transition metal ions which cause oxidative damage to cell membrane in alloxan diabetic rats. The present work revealed that treatment with the water extract of tested plants and their mixture decreased LDH activity in serum, and was decline to normal value except Ferula assafoctida which showed a significant increase which may be attributed to the dose used . Therefore, it is conceivable to assume that these plants may exert a protective role against the destructive effect of alloxan.

From the above mentioned results, it was clear that the present studied plants induced stimulation for insulin secretion .They have effective propitiators rather than initiators of insulin release. Metal ions contained in these plants and/or other constituents like, alkaloids, play a role, not only in potentiating insulin release but also ameliorating hyperglycemia by increasing insulin secretion and/or insulin sensitivity and some damage effects of alloxan injection in vivo. More detailed studied on each plant and their mixture must be done at different dose and different periods of observation are needed before reaching a clear cut conclusion about the future of these plants for the treatment of diabetes mellitus.

\section{References}

1. Al-Awadi,F.M. and Shoukry, M. (1988): The lipid lowering effect of an antidiabetic plant extract. Acta. Diaabetol.lat., 25:1-5.

2. Al-Awadi,F.; Farania, H. and Shamte, U.(1991): The effect of a plants mixture on liver gluconeogensis in streptozotocin induced diabetic rats. Diabetes Research, 18:163-168.

3. Annamala, P. T. and Augusti, K. T.(1980): Studies on the biochemical effects glibenclamide on alloxan diabetic rabbits. Exprentia, 36(A):383-384.

4. Aoki, K.; Nakajima, A; Mukasa, K; Oswawa, E.; Mori, Y. and Seihara, H. (2003): Prevention of diabetes, hepatic injury colon cancer with dehydroepiandrosterone. J. Steroid.Biochem. Mol. Biol. 85 (2-5): 469-472.

5. Bever. B.o. and Zahnad, G.R. (1979): Plants with oral hypoglycemic action. Quartz.J J. Crude Drug Res., 34:139-169.

6. Campbell, D.B.; Lavielle, $R$ and Mathan, C.(1991): The mode of action and clinical pharmacology of gliclazide. Diab. Res. Clin. Pract., 14 (2):512-536

7. Casson PR. Faquin LC, Stentz FB ( 1995 ) : Replacement of DHEA enhances - T lymphocute insulin binding in postmenopausal women. Fertil steril 63 : $1027-1031$.

8. Chevallier,A.(1996): The encyclopedia of medicinal plants. $1^{\text {st }}$ Amercian ed.Pp.: 36, 237.

9. Coleman, D.L.; Leiter, E.H. and Schwizer, R.W.(1982):Therpeutic effects of dehydroepiandrosterone (DHEA)in diabetic mice. Diabetes, 31:830-833.

10. Dawson, K. (1998): Focus on elderly patients.Diabetes, 47:1369-1467.

11. Duke, J.A.(2002):Hand book of medicinal Herbs. $2^{\text {nd }}$ ed. United states of America,Pp.: 15-519.

12. Ebihara, K.: Ogawa, Y. and Masuzaki, H;(2001):Transgenic over expression of liptin rescues insulin resistance and diabetes in a mouse model of Lipoatrophic diabetes. Diabetes., 50(6):1140.

13. Evans, W. C.(2001): Trease and Evan's pharmacogosy .WB sanuders company LTD.London.

14. Ganong, W.F. (2003): Reviewof medical physiology, $23^{\text {rd }}$ ed., Lange med. Puplic ,Chapter.19:306-326.

15. Gold, A. H. (1970): The effect of dibetes and insulin on liver glycogen synthetase activation.J.Biol.Chem.245:903-905.

16. Guyton, A.C. and Hall,J.E (2000):Text book of medical physiology. Endocrinology and reproduction. Insulin, Glucagon and Diabetes Mellitus. $10^{\text {th }}$ ed. W.B. Sounders Company in U.S.A..

17. Hales,C. N. (1986): The glucose fatty acids cycle diabetes in the biology basis of 
medicine.Bitttar, E. and Bittar, N. Academic press London.

18. Hansen, P.A.; Han, D.H.; Notle, L. A.; Chen, M. and Holloszy, J.O. (1997): DHEA protects against visceral obesity muscle insulin resistance in rats fed a highfat diet .AM.J.Physiol., 273:R1704-R1708.

19. Hayashi, S.(1998):Essential oil of Boswellia. The Journal of Essential Oil Research, 10:25-30.

20. Heber, D. (2003): Herbal preparations for obesity: Are they useful?.Primcare., 30(2): 441-463.

21. John, D. (1982): Clinical laboratory Methods.C.V. Mosby Co., USA, $9^{\mathrm{Th}}$ Ed.P.580-581.

22. Joseph, H.R. (1955): The determination of sugar in blood and spinal fluid with an throne reagent.J.Biol.Chem.212:335-343.

23. Kachmar, J.F and Moss, D.w. (1976): In Fundamentals of clinical chemistry, $2^{\text {nd }}$ ed.NW Tietz, Editor WB Sounders, Philadelphia, P652.

24. Loviselli A, Pisanu P, Cossu E, ( 1994 ) : Low level of DHEA - sulfate in adult males with insulim - dependent diabetes mellitus, Minerva Endocrinol19:113-119

25. Malaisse, W. J.(1982): Alloxan toxicity to the pancreatic B-cell. A new hypothesis. Biochem.pharmacol.(31):3572 .

26. Meral, I.; Yener, Z.; Kahraman, T. and Mert, N. (2001): Effect of Nigella sativa on glucose concentration, lipid per oxidation, anti-oxidant defence system and liver damage in experimentally induced diabetic rabbits. J. Vet. Med.A. physiol. Clin. Med.48(10)593-599.

27. Michael, H.R.; Gordon, I.K. and Wojciech, P. (2003): Histology a text and atlas. Digestive system111:Liver, gallbladder and pancreas. $4^{\text {th }}$ ed.New York

28. Nakashima, N.; Haji, M.; Sakai, Y.; One, Y.; Umeda, F. and Nawata, H. (1995): Effect of dehydropiandrosterone on glucose uptake in cultured human fibroblasts. Metabolism,44 (4):543.

29. Okyar, A.; Akev, N.; Baktir, G and
Sutlupinar, N. (2001): Effect of Aloe vera leaves on blood glucose level in type I and type II diabetic rat models. Phytother.Res.,15(2): 175-161.

30. Olefsky, J.M. (1981): Insulin resistance and insulin action. An in vitro perspective. Diabetes, 30:148-162.

31. Perrini,S.; Natalicchio, A. and Laviola, L. et al. (2004): Dehydropiandrosterone stimulates glucose uptake, in human and murine adipocytes by inducing GLUT 1 and GLUT 4 translocation to the plasma membrane Am. Diabetes Association, Inc. Diabetes, 53:41-52.

32. Puri, D.; Prabhu, K. M. and Murthy, P.S. (1994): Hypocholesterolemic effect of the hypoglycemic principle of fenugreek (Trigoneela foenum graecum) seeds. Ind.J.Clin., Biochem., 9:13.

33. Reeves, W.G. (1983): Insulin antibody determination: Theoretical and practical consideration. Diabetologia, 24:339-403.

34. Sheela, C.G. and Augusti, K.T. (1992): Antidiabetic effects of Sallyl cysteine sulphoxide isolated from garlic, Allium sativum Linn. Ind. J. Exp. Biol., 30:523526.

35. Snedecor, G.W. and Cochran, W.G. (1980): Statical methods. Oxford and J. B. H. Puplishing Co., $7^{\text {th }}$ ed.

36. Tietz, N.W. (1986): Text book of clinical chemistry. W.B. Saunders Co., London, Philadelphia, Pp.:1389-1390.

37. Vignati, L. and Cunningham, L. N.(1985): Exercise and diabetes.In Joslin's diabetes mellitus, $12^{\text {th }}$ ed.Marble A.Krall, L.P..; Bradely, R. F.; Christ Lied, A.P.P.and Soledner, J.S. (eds) philphadelphia. P. A. Lea and Febiger. Pp: 453-464.

38. Yadav, P.; Sarkar, S. and Rhatnagar,D .(1997): Action of copparis deciduas against alloxan-induced oxidative stress and diabetes in rat tissues. Pharmacol. Res.,36(3):221-228.

39. Yen, T.T.:Allan, Z.A.:Pearson, D.V.: Acton, J., M. and Greenberg, M.D. (1977): Prevention of obesity in mice by dehydropiandrosterone. Lipids, 12:409-413. 


\section{تأثير بعض النباتات الطبية على بعض المعاير الكمياء الحيوية فى الجرذان

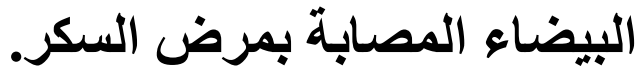

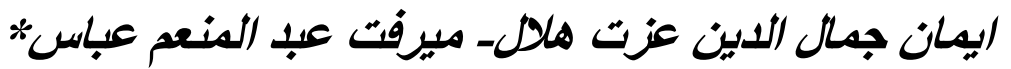 قسم علم الحيو ان ـ كلية العلوم(بنات) ـ قسم الكيمياء الحيوية* ـ كلية طب البناتـ

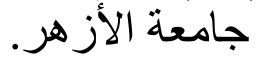

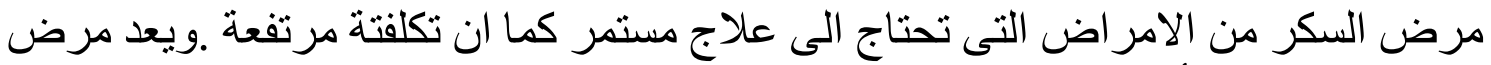

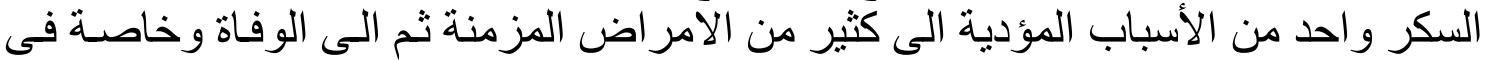

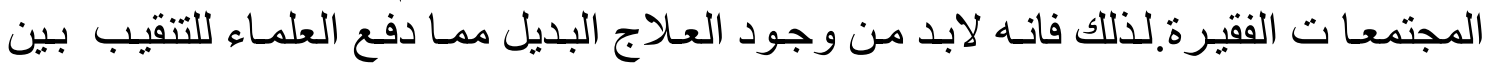

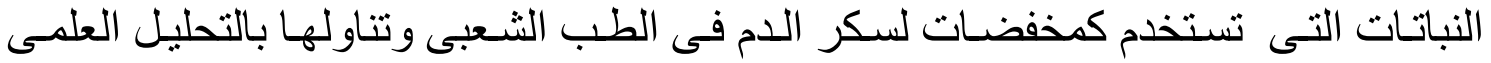

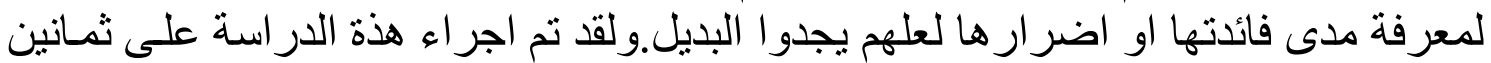

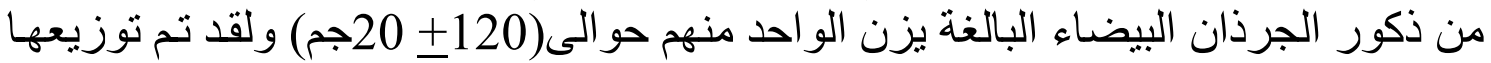

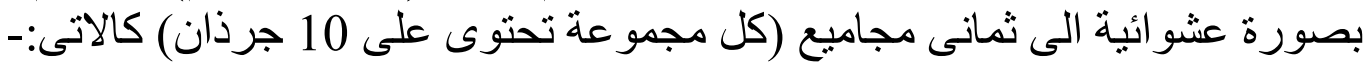

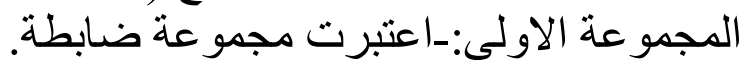

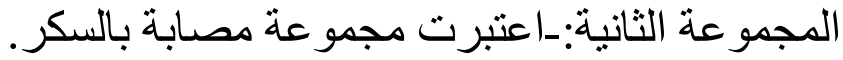

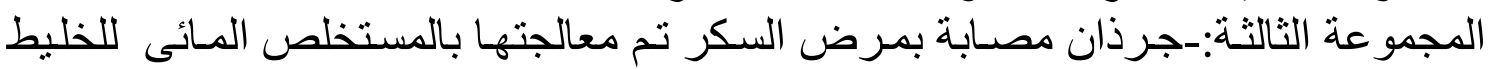
(0.5جمع/120جم من وزن الجسم).

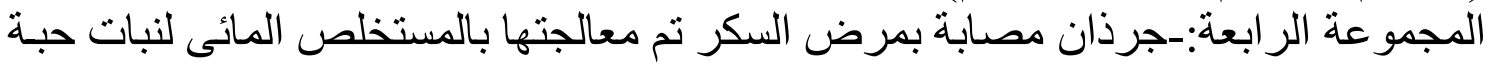

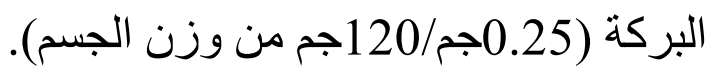

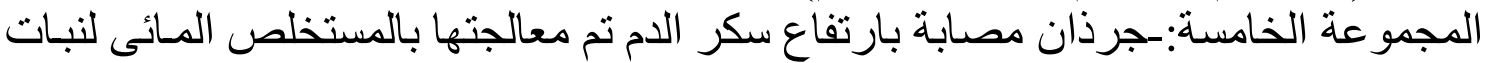

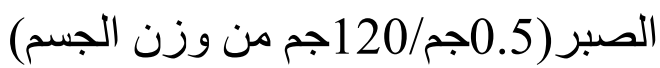

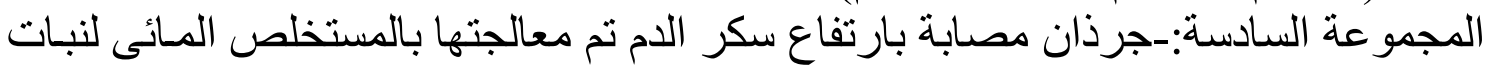

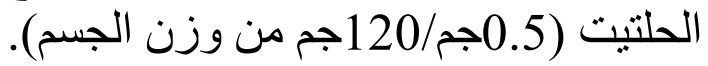
المجمو عة السابعة :-جرذان مصابة بارتفاع سكر الدم تم معالجتها بالمستخلص المائى لنبات

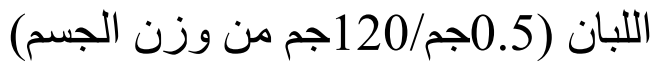
المجمو عة الثامنة:-جرذان مصابة بمرض الدمن السكر تم معالجتها بالمستخلص المائي لنبات المر

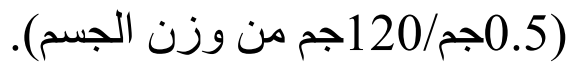

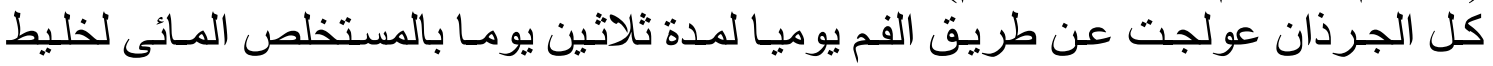

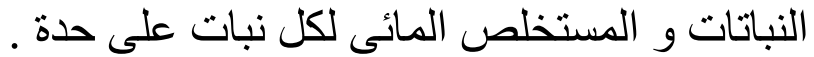

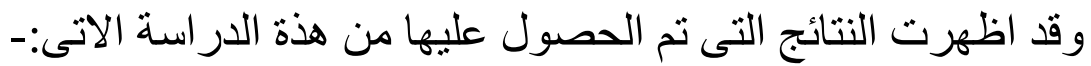

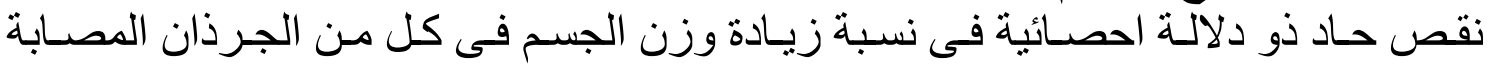

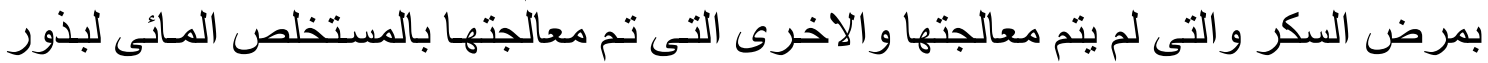

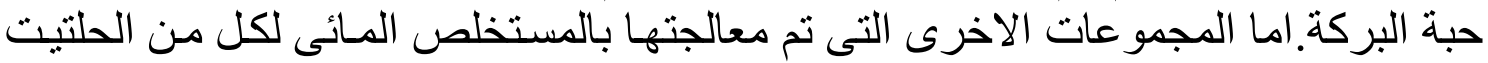

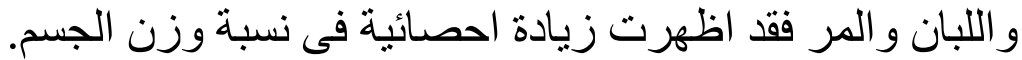

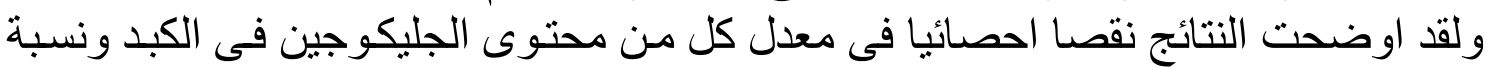

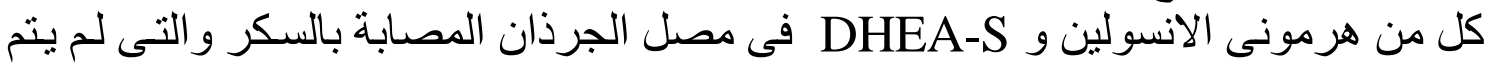
معالجتها و الجرذان المعالجة بحبة البركة و الحلتيت ومن ثم اظهرت زيادة ملحوظة في نسبة بلية 


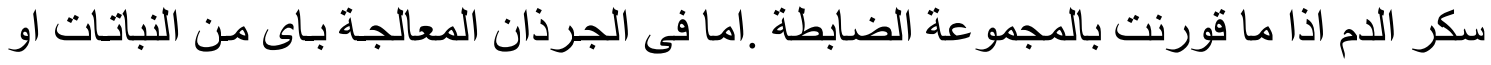

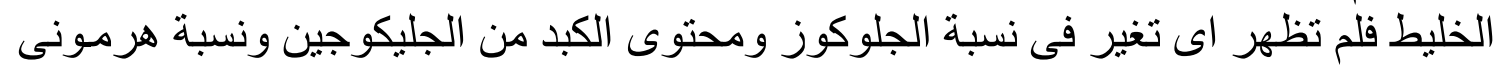
DHEA-S

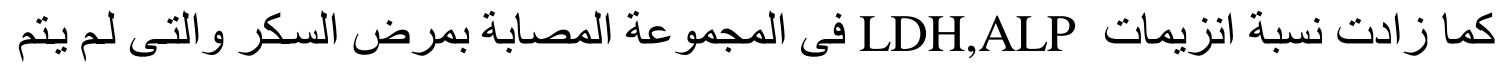

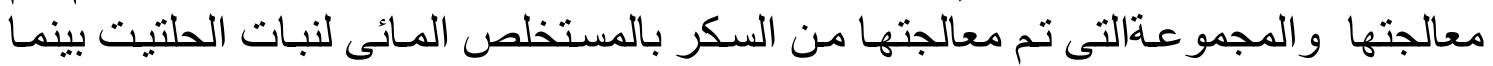

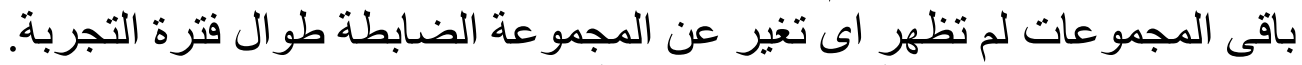

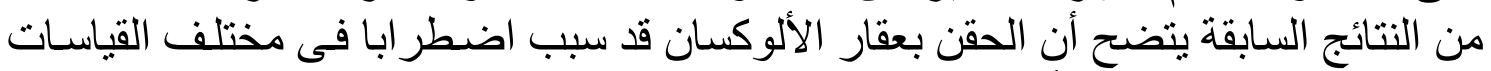

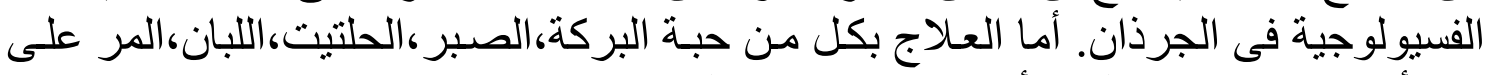

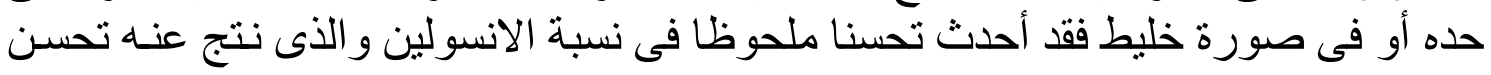

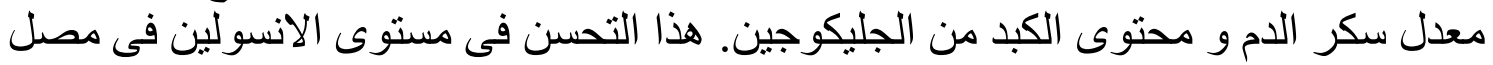

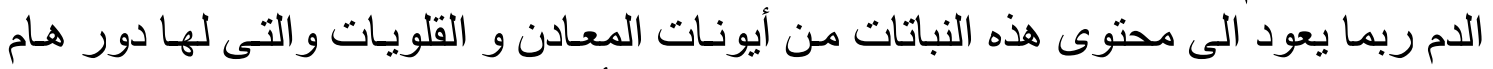

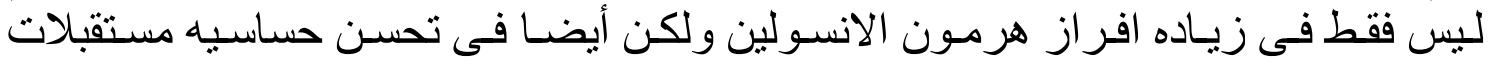

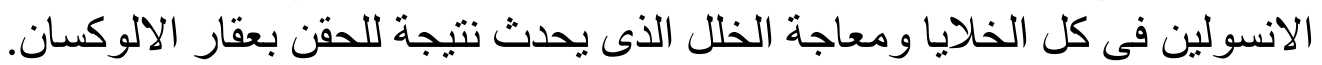

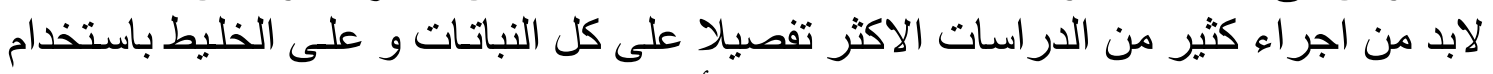

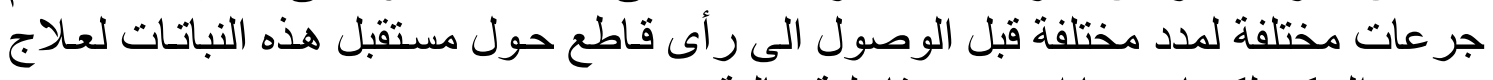
مرض السكر لكنها مبدئيا اوضحت فاعلية عالية. 